\title{
Private Investment and Business Opportunities in Ethiopia: A Case Study of Mettu Town in Ethiopia
}

http://doi.org/10.21272/bel.3(4).91-104.2019

Satya Narayan Singh, ORCID: http://orcid.org/0000-0002-1494-4489

$\mathrm{PhD}$, Associate Professor, Department of Economics, Faculty of Business and Economics, Mettu University, Mettu, Ethiopia

\begin{abstract}
Investment has a very crucial role from the point of view of national economy. For any country, investment, as well as business ethics, is necessarily to create a good business environment. The rate of growth of the economy and employment is directly related to the level of investment and business ethics. This study mainly concerns about the contribution of private domestic investment towards multidimensional business opportunities including employment creation in Mettu Town of Ethiopia. Its main objective is to assess the contribution of private domestic investment towards employment creation in Mettu town. The research is conducted by using both primary and secondary data. Primary data are collected through interview and questionnaire and secondary data are gathered from published and unpublished materials. The researcher used purposive and systematic random sample techniques as a major advantage of easy administer relatively convenient and less time-consuming. The researcher collected data from 51 investors from a total of 106 investors in the service, industrial and agricultural sectors to assess the contribution of private domestic investments towards employment creation in Mettu town. The method of analysis is the descriptive analysis which includes statistical tools such as table and percentage with interpretation in order to achieve the objective of the study. The results from the descriptive analysis of private domestic investment towards business opportunities and employment creation are found significant despite different challenges of investment such as high-interest rate, lack of capital, high taxation, poor infrastructure, etc. Thus, to achieve private domestic investment the measures include government motivation, good investment policymakers who take a remarkable decision in order to facilitate the growth of investment which results in increasing the participation of private investors.
\end{abstract}

Keywords: private domestic investment, business opportunities, business ethics employment opportunities, industrial sector, agriculture sector, and government policies.

JEL Classification: G00, G11.

Cite as: Singh, S. N. (2019). Private Investment and Business Opportunities in Ethiopia: A Case Study of Mettu Town in Ethiopia. Business Ethics and Leadership, 3(4), 91-104. http://doi.org/10.21272/bel.3(4).91104.2019.

(C) The Author, 2019. This article is published with open access at Sumy State University.

\section{Introduction}

\subsection{Background of the study}

Investment refers to the purchase of several goods and services that can be used for the production of other goods and it increases the productive capacity of the economy. Developed countries have excess capacity to invest. Private domestic investment is an essential activity for sustainable growth and increases the productive capacity of the economy. Privet investment plays a significant role in the world that is it increases employment opportunity, raises the level of output, increases export to the international market, increases the level of per capita income, reduces poverty and raises urbanization (IBD).

Investment is the hope of most countries to increase this level of income. Over the last three decades investment has accelerated birth taking and is now shaping the global economic land scope in either form of government or private. Notwithstanding the type of investment, it is the backbone of the world economy in the recent phenomenon. Today multinational cooperation was operating worldwide with many employees. The investment flow may be foreign direct investment or domestic investment (world investment forum report, Sep. 6, 2010).

Foreign investment has been grown faster in the current time. It brings not only fresh capital, technology, and idea to new markets. It also brings jobs for the invested countries. The foreign direct investment flows 
ISSN (online) - 2520-6311; ISSN (print) - 2520-6761

are the vital current that can help restore global economic growth. In the absence of investment development is unthinkable (world investment forum report, Sep. 6, 2010). Declining investment ratios and levels are a problem, firstly because investment matters for growth, and secondly because low investment increases vulnerability in the economy (Oshikoya, 2001). Workie (1996) on constraints to entry, operation and expansion of private investment in Ethiopia using investor level information showed that bureaucratic procedures, a lack of infrastructure, power supply problems and access to finance were the leading constraints for operations.

The private sectors are the core of any approach designed to address the job challenge, as it provides some 90\% of the job in the world (khan and Reinhart, 1999). Most foreign investors and domestic investors are private sectors. Private investment in both domestic and foreign is a major source of growth, employment and development. Since 2000, investment worldwide and especially in developing countries, which have a low income, has grown quickly, reflecting stronger economic growth and confidence in the renewed emphasized place on the private sectors by many developing country governments.

Developing countries, emerging economies and countries in the transaction have come increasingly to see the private sector investment as a source of economic development and modernization, income growth, technology transformation and development (report of the committee on international investment and multinational enterprise, Dec., 2001). Developing countries, especially sub-Saharan countries have been providing different incentives for investors to attract them to the country. Before two decades ago, the level of private investments of Ethiopia had been minimal. Factors that have been explored as attributable to investment changes include; changes in income, the cost of capital, the rate of return, public sector investment, credit to the private sector, taxation, the terms of trade, the debt level, the exchange rate, development of urbanization, among others (Ronge and Kimuyu, 1997). The political land scope of that time was unsuitable for private investors. The most known investments were made by the government. The problem is that we do not have a strong private, due to the activities only done by the government. So, it's obvious that private investments lead to faster economic growth those made by government (Yusuf, 2002).

Since recent times, Ethiopia has adopted a special policy to develop the investment flow in the country. Abaka and Mayer (1994) argued that SMEs give the owner the opportunity to maximize profit without necessarily hiring labour and also to bring about the sustainability of the SMEs as skilled labour is retained within the business. The country believes that like other countries without private investment development cannot be achieved (the Preamble of proclamation no 769/2012). To encourage this investment the state has adopted different incentive mechanisms. Incentive mechanisms like tax incentives or exempt from taxation in some selective investment fields are introduced by the government (article, 23 of proclamation no 769/2012). In Mettu town, there are a small number of investment flows in each sector of economic. However, the current investment flows are the result of the Ethiopian investment policy. It increases from time to time in each sector. The contributions of private domestic investment sectors are alarmingly increased by capital accumulation, including all new investment in land, physical equipment and human resource through improvement in health education and job skills and growth in population and hence eventually growth in the labour force and technological progress which is a new way of accomplishing tasks. Ethiopia has great potential for investments for several reasons, among the top-performing economies with an average GDP growth of $11 \%$ per annum since 2004 (MOFED).

Private domestic investment is a key source of employment wealth creation and innovation as such as private investment can contribute to sustainable development and poverty reduction through pay tax to the government, capital investment, and construction of new factories, providing efficiency and increasing productivity.

\subsection{Statement of the problem}

Studies on investment especially in developing countries have been carried out. Nevertheless, empirical evidence on the determinants of private investment growth has been limited (Khan and Kumar, 1997; Siraj, 2014). Investment increases the level of living standard of people. Moreover, investment is vital for every national economic development. Always investment comes with different benefits or both investors and the invested countries (report of world investment forum September 6, 2010). The overall benefit of investment for developing countries economics well documented. Private investment assists human capital formation, help individuals to create employment opportunity and enhance enterprise development (World Investment Forum, 2010). Deneke (2001) concluded that unclear land policy, compounded by investors' fear of political instability, has impeded private sector development. Getachew (1997) studied the determinants of private 
industrial investment in Ethiopia using descriptive statistics to analyze micro-level determinants. He found that the real interest rate did not have a significant impact on private investment in Ethiopia. Were (2001) finds that among institutional factors, lack of rule of law, high corruption and real exchange rate distortions are the most detrimental for investment. The study revealed that private investment was positively affected by credit disbursement to the private sector in Ethiopia.

All these contribute to higher economic growth, which potential tool for alleviating poverty in developing countries. The main constraint to private investment in Ethiopia what explained in the poor performance of this that fair policy. It is all the factors of private domestic investors have been complaining about such as shortage demand in abolish to compute with cheap import, bureaucratic, incompetence, unfair competition, etc. These all factors of domestic investor's complaints cause many macroeconomic problems such as unemployment, low level of standard, low income, etc. That needed serious and quick attention if the investment atmosphere is improved and domestic investors play the role, they are expected to have in developing the national economy (Degefeandnega, 1999).

As one of the Ethiopian towns, in Mettu town there are many investment projects such as it including supply material construction, hotel and tourism, education, health and other service sectors. Other investment projects which are around 111 projects are underway and are expected to be completed in the 2009 Ethiopian budget year (Mettu information sector). The projects are engaged by public and private investors. Private domestic investments are increased from time to time. In the budget year of 2009 and 2010of Ethiopia around 106 investment projects amount to 1 billion $\mathrm{Br}$ launched in Mettu town have gone operation (Mettu information Centre). Investment flow as a direct relation to employment creation, the investment projects which undertake in Mettu town have their own contribution to economic development and employment creation.

However, there is not enough research conducted concerning the contribution of private domestic investment on employment creation. To fill this gap the researcher is interacted to conduct this research in Mettu town and the contribution of private domestic investment on employment creation. It would reduce the amount of unemployment in Mettu town and promote employment creation to pass our county to industry and using technological progress.

\subsection{Objective of the study}

\section{General objective of the study}

The general objective of the study would be to assess the contribution of private domestic investment towards business opportunities through employment creation in case of Mettu town.

\section{Specific objective of the study:}

to assess the precondition to establish a well-organized private domestic investment in order to create employment opportunities;

to identify the potential of Service, Industry and Agricultural sectors to enhance business opportunities in order to create employment opportunities and poverty reduction.

\subsection{Research questions}

Is private investment the solution to the unemployment problem in Mettu Town in Ethiopia?

Is the government incentive strong enough to create a favorable business opportunities environment?

$>$ Is private investment a wholesome option from the government perspective in terms of benefits it offers to society?

\subsection{Significance of the study}

Investment was a burning issue to bring economic development especially in the least developed countries like Ethiopia, the investment will have an important rate of capital information for least developing economics. Important of this study was to indicate what needs to be done to improve the performance of the private investment in Mettu town. The information gap between prospects and obstacles private investment in the Mettu town would be interrelated. The study will also recommend some possible policies that can probably smooth the growth of the investment. Moreover, the paper will also support further research on the same line of subject as reference. 


\subsection{Scope of the study}

This study would be limited to Mettu town because of the limitation of time to be taken for this research paper. Moreover, the study covers the year from 2007 up to 2010 E.C. The research also limits himself to assess the contribution of private domestic investment towards employment creation to come up with more rear information rather than taking the aggregate investment contribution to employment creation. This decided by research to overcome financial constraints.

\subsection{Limitation of the study}

The focus of this study was limited only in Mettu town. In carrying out the study, the researcher has faced some problems that put challenges on the study. Some of them are lack of financial support, unfulfilled response, insufficient written material regarding the sub-sectors, lack of enough time and others were restricted the research process but the researcher tries to manage them and conducted the research.

\section{Literature review}

\subsection{Theoretical literature review}

Private investment in goods and services or in terms of distributing good profit the domestic investment committed comparatively high by domestic investors. Obviously for a developing country in order to develop its resources to distribute and generate employment in all sectors of the economy the private investment is an essential way (Jir Jock, 1965).

Investment does not have a tight link to growth in the short run, and not even much of a link in the long run in Africall (Dollar \& Easterly, 1999). Investment promotes economic growth and is a contribution to a nation wealth when people deposit money in a saving account in a bank, for example, the bank may invest by loaning the funds to various business companies. This firm, in turn, may invest by loaning the equipment to increase its production. In addition to borrowing from a bank, most of the cooperative's stocks are bonded to raise capital for business expansion. Government also bonded to obtain funds for investment in such projects as the construction of dams, roads, and schools. All such investment involves a present sacrifice of income to get and expected future benefits. As a result, investment raises nations standard of living (World bank, 1994).

Investment may be defined as expenditure on real capital goods. Thus, it is the amount which is the capital stocks of the firms or an economy increase because allows for the replacement of capital which is crapped. In the same manner, private investment is also defined as the difference between total domestic investment and consolidated public investment. Private investment has been mostly studied in detail in industrial countries. However, studies on private investment in developing countries are few and do not seem convergence of views about the factor which affects private investment behaviour. In 1997 Sub Saharan Africa on average experienced the increase in private investment growth domestic product (GDP). The growth of the level of private investment in Sub Saharan Africa is still among the lowest (Patrick, 2008).

Many scholars have defined investment used in production in capitalist economies as such where much attention is focused on business investment, physical capital, building, and equipment. But investment is also taken by government, institution and household. It includes the acquisition of human and intangible capital as nonprofit well physical capital. In other word, investment can also be defined as time term investment as the use of the money to earn income or profit. The term refers to the expenditure of funds for capital good. Items like factories, firm, equipment livestock and machinery which are used to produced other goods and services. As Keynes stated in this book in entitled general theory of employment, interest and money (1936) he was the first to call attention to the existence of independent on the prospective marginal efficiency of capital.

Marginal efficiency of capital in the rate of expected profitability from capital invested or rate of return over cost or the expected profit of capital asset. He suggested that investment good could be raised either by marginal efficiency of capital or reducing the interest rate (IBID). In addition to the above variable he introduced the expectation firm about future demand for output, volatility of investment, uncertainty and other none economic variable such as political, environmental, bad weather condition and the like determine investment. Again, Keynes stated the marginal efficient capital is determined by the other factor. These are the prospective yield of a capital asset, the supply price or the replacement cost of the asset.

Another economist Hirschman stated the central question in economic development is the rapid accumulation of capital which is the question of the level of living and investment in a given countries 
economy. In the theory of economic growth, attention is properly centered on two points, which means the generation of saving and availability of investment opportunity and their productivity. In explaining the importance of investment. Hirsch identifies the linkage effects of forward and backward linkage. Forward linkage is an encourage of investment in subsequent stage of production and backward linkage is those that promotes investment in the earlier stage of production.

So economic development should be selective. According to him investment appropriate development policy will enable underdeveloped countries to get out of the vicious circle of poverty and bring economic growth. A vicious circle of poverty means when the country has low income, low level of living, low investment, low productivity. As pointed out investment or capital accumulation is the major determinant of economic growth and regarding investment as the factor which describes the growth process in time labour may be abundant in less developed countries, output remains limited because of capital, therefore, an increased investment is a necessary condition for the development. In orthodox economic models investment has no effect on the long-run rate of economic growth, which is dependent on exogenous improvements in technology. Traditional, neoclassical growth economic assumes that capital accumulation is subject to diminishing returns, such as that in the long-run rate of growth is independent of the rate of investment. Thus, the increased investment may have a short effect on growth, but as diminishing return set in the increments to growth would decline until output settled at a new higher level, but the previous rate of economic growth. However, an important role in financial development in mobilizing domestic savings to finance investment. Overall, the evidence supports a positive association between financial development and domestic investment in Africa as in other regions (Ndikumana, 2014). Investment is, therefore, not central to orthodox or exogenous growth models although it is not completely unimportant, because it can help to explain the shift to higher levels of income (Atkinsan with Livesey and Milward). The implication of the traditional neoclassical approach is that economic with similar savings and population growth rate should coverage to the same level income per person. Thus, if for whatever reason countries' initial condition is such that per capital income levels differ, their subsequent growth rate will be inversely related to the level of output per person, with the scope of catching up being dependent on the extent of the productivity gap (IBID).

The existence of persistent difference in growth rate and in some cases evidence of divergence in growth rate cannot be easily accommodated within traditional, neoclassical growth theories. Alternative models suggest the importance of increasing or (none decreasing returns to capital. Some of these models remain neoclassical. With the full employment and the competitive process reduced to alternative measures of market structure. Other outside the neoclassical paradigms such as the cumulative causation models of Kaldo and Myradaland do not assume full employment or that the factor endowments, in general, are exogenous determine (IBID).

The major contrast between the new and traditional neoclassical model is that the former treat technical progress as an endogenous element that can be influenced by cooperating investment behaviour and public policies. Thus, policies that promote investment or at least a certain kind of investment in education may be able to influence the long-term growth rate (IBID).

There is different to stimulate investment, this is responsible for the rise of the level of investment at the same time level of employment and income can be raised. This measure may be fiscal, monetary and other measure has been suggested to stimulate investment in an economy. A fiscal policy like tax and government expenditure affects investment. Lower tax rate stimulates, and government expenditure raises the level of investment. A monetary policy such as price policy (price stability) and low-interest rate affects the level of investment positively. Other like technological change and innovation, the abolition of monopoly privileges and encouragement of competition and economic planning affects the level of investment (Sern and Soliman, 1992).

Devaluation is another variable, which affects investment through several channels. First, it raises the cost of imported input and income and thereby it affects the probability of investment. To encourage domestic as well as foreign investors different incentive are given. Incentives are defined as any measurable economic advantage afforded for specific enterprises by the government in order to encourage them to behaviour in a certain manner (Cu but and Daianian, 1990).

Saving and investment are the most basic pillar of economic growth. Saving is that amount of the value of production or national income that is not the value of production or national income that is not spent on consumption. Saving is one way of providing a resource for investment. There is a strong correlation between economic developments; investment and saving Investment that is not financed from the investors' 
ISSN (online) - 2520-6311; ISSN (print) - 2520-6761

own resource is financed. From saving or others hence any increase in the rate of world capital for formation will be financed by the relocation of income somewhere uses in the world way from consumption spending (UNCTAD, 1992).

By large business facilitation measures such as incentive schemes and promotional efforts as investment determinant they contribute toward investment decisions and can play a supporting role in attracting investors (Goff. T. G, 1978). One aspect of economic performance is how well an economy uses its resources. Since works are the main resource, keeping worker employed is the major concern of policymakers. Employers are people who perform any paid work as well as those who have a job but absent from work because of illness; vacationed, etc. (Samuelsson, 1998). A worker is said to be employed when he is engaged in act of production, usually it is thought that the worker is employed at a particular wage rate. According to the professor Sen, there are three important aspects of employment: the income aspect, the production aspect, the recognition aspect. The income aspect indicates that the employment of a worker yields an income to him. That is when a worker sells his labour service for a wage is accepting employment in exchange for a wage or some earning. The production aspects of employment suggest that employment leads to the generation of output. When a worker is full employed, he must contribute to an increase of gross national product (GNP) the worker employment is judged by the fruit disfavor. This marginal product must be positive.

A worker whose marginal productivity is zero and employed in business activities also gained full or fruitful employment. He is said to disguise unemployment. The recognition aspect of employment implies that employees give a worker the recognition of being engaged in some occupation, which makes his life comfortable, or worth living. Among the objective of macroeconomic policy employment is one. The extent of employment also must be taken under consideration full employment; the concept of full employment is not easily defined. Many authors define it in different ways.

Keynes suggested that employment may mean the absence of involuntary unemployment he argues that full employment level is reached by the economy when the real wage as equal to the marginal utility of employment. At lower wage, no worker would be willing to work at taking up the job. Thus, anybody is not willing to work at the prevailing. Therefore, there is voluntary unemployment. In very simple logical sense may mean that the total available supply of labour is completely absorbed in given full employment.

Beverage, on the other hand, defines full employment in way, which means having always dour vacant jobs than unemployment then; it means that jobs are at fair wage of such kind and so located that unemployed men can reasonably be expected to take them. When the objective of macroeconomic fail to achieve to its goal the economy at a given country may face unemployment. Unemployment is defined as a person who is out of work and currently actively looking for a work and currently available for work (ILO, 1998).

Keynes argues that the role of government is important in reducing unemployment problem. He stated aggregated demand the sum of consumer spreading investment and expenditure and net export. Unemployment in the least developing country is due to a shortage of skilled labour technical knowhow. So, by improving the educational opportunity of the people is possible to enhance capital formation expanding employment opportunity (Godferly, 1980).

Generally, from the above two points, we can conclude that investment and employment creation has a direct relationship that means increment investment leads to increasing employment opportunities. On the other hand, decreasing investment leads to a low level of employment opportunities. Due to that reason government motivates the investors to improve the positive between investment and employment creation in deferent wise such as access to credit, tax exemption, free provision urban land, etc.

\subsection{Empirical literature review}

The impact of governance, credit availability, exchange rate and interest rate on private investment is the main concern of research in Ethiopia, without much emphasis on the infrastructural facilities in the country (Khan \& Reinhart, 1990). The empirical analysis of the impact of investment on growth has yet to provide clear results. In a part, this reflects a statistical problem in measuring the relevant variable, in determining the direction of causation and separating out of the contribution of the deferent variable (which often move together). Furthermore, the impact of investment on growth (especially intangible investment, such as training) may be slow and with long-time lags, their by further complicating empirical assessment (Atkinson with Livesey and Milward, 1998). A further limitation of many orthodox growth theories is that they assume that the growth of employment is independent of the investment. Rod thorn (1995) has shown this too 
incorrect. Low investment, especially in manufacturing, through its impact on capacity, has been a significant factor behind the rise in unemployment in Western Europe during the twenty years (IBID).

The empirical investigation has shown business investment to be less responsible to interest rate and more dependent on business expectation about future demand profit, technical change in production method and the expected relative cost of labour and capital (Britannica, 2007).

Because investments increase an economy's capacity to produce, it is the factor responsible for economic growth. For growth to occur smoothly, it is necessary that severs intended to save the same amount of those investors wish to invest during a time period. If intended saving exceeds intended investment, an employment may result and if exceeds saving, inflation may occur (IBID). Workie (1979) analyzes the determinant and constraint of private investment and found that private is determined by the availability of finance in Ethiopia. Furthermore, James B.J. (2010) also indicates that increase availability of credit contributes positively to private investment in Malaysia. On the other hand, there are empirical studies which are demonstrated that credit appears to have had a significant negative impact on private investment. For example, AKPALU (2002) found in a study which he conducted in Sudan that credit availability and public finance were found crow out private investment.

Another study made by green and Villanueva (1998) indicated that private domestic investment was negative and significantly related to real interest rates Similarly Hulng (2002) in a study on determinants of private investment in Ghana found that real interest was negative and significantly associated with private investment. On the country, Getachew (1997) and Workie (1997) in their study conducted in Ethiopia found out that a real interest rate didn't have a significant impact on private investment. A change in terms of trade is one the determinant of private investment in the country. Ambachew (2011) found out in a study conducted in Ethiopia that the effect of openness to trade on investment was positively related to private domestic investment. Another study made by Yosseph (2010) in Ghana shared that the ratio of trade to gross domestic product (GNP) affects investment negatively.

\subsection{Investment policy review}

The current economic policy of Ethiopia adopted by the government pursued a market-oriented economy by rationalizing its role and enhancing participation of the private sector. To develop the economy and stimulate the growth of the economic reform program was launched in 1992|93 which was further strengthened by the government to redress the structure bottlenecks of the Ethiopian economy (MOFD, 2000).

The exchange was devalued, government monopolies were abolished, domestic markets and imports were liberalized, and export disincentive has been largely rectified. A major structural reform in the monetary and financial sector during the reform program has been the introduction of a competitive financial sector, which includes the establishment of a private bank and insurance companies. Moreover, price of goods and services decontrolled and left to be determined by the operation of liberalized markets for both inputs and outputs provides the basis for free participation of the private investment and improvement employment opportunities.

The government of the Federal Democratic Republic of Ethiopia has also introduced legal frame and operational guidelines for creating conductive environment for the enhancement of private investment in the country. The legal framework in the form of subsequently introduced and revised proclamation, regulation directives and lines are issued with a vehicle to making private investment competitive darken, sustainable and pillar to macro development (MOFD, 2006).

\section{Methodology of the study}

\subsection{Description of the study area}

The research studied is carried out in Mettu town of Ethiopia and Mettu is the largest town in I/A Bor, with the population around 53,906 in the year 2010 and it stands at a pivotal junction particular of the road to Gambella, JImma and Nekemte the capital of Eastern wollegga.

Mettu a rapidly developing town it is located in the northern part of Ethiopia about 600km north of Addis Ababa. It has strong historical and cultural links to Eastern wollegga. The town has expanded as 2010 there is persons and on-going archaeological project as well. Due to a long-term business development aim at creating optimal job opportunities for the youth, the town has become the hometown for many industries, agro processing companies, and service centres (Mettu investment office 2010). 


\subsection{Source of data}

Both primary and secondary data have been used for the research purpose, primary source of data obtained through questionnaires' and interviews to those individuals who are engaged in investment activities in Mettu town. Furthermore, the interview for the managers of the investment office was also taken into consideration. However, the secondary source data includes all types of published and unpublished materials related to private domestic investment.

\subsection{Method of data collection}

Both primary and secondary data are to be used through questionnaires and interviews as much as possible so to give the respondent full freedom and to detailed information. Secondary data are carefully collected from review of related document reports of economic journalist cities of PDI development strategy and internet. The uses of secondary sources in order to strengthen the information required and purpose necessary suggestion for the business opportunities and creation of employment.

\subsection{Sampling techniques and sampling size}

The study would use systematic random sampling techniques to select data among manufacture sector and sample respondent of Mettu town because a systematic random sampling is: easy to gather data, to minimize cost, to save time and by using the above techniques among the three sectors such as service, industry and agriculture sector the data was selected as sample from 106 investors and 51 respondents from these three manufacture sectors.

From these three groups, the researcher selected 99 samples from a total of 93 service sectors investors, 5 samples from a total 5 of industrial sector investors and 2 samples from a total of 2 agricultural sector investors by using sample random sampling techniques due to similarity investors, to give equal chance for each investor and avoid bias. Accordingly, the researcher has selected 51 from a total of 106 in service, industrial and agriculture sector to assess the contribution of private domestic investment towards employment creation Mettu town. This study applied a simplified formula in order to determine the required sample size $90 \%$ confidence level and $10 \%$ of precession level.

Yamane (1967) provides a simplified formula to calculate sample size:

$\mathrm{n}=\mathrm{N} / 1+\mathrm{N}(\mathrm{e}) 2$

Where $\mathrm{n}=$ sample size;

$\mathrm{N}=$ total population and

$\mathrm{e}=$ sample error;

$\mathrm{N}=106$

To take a $10 \%$, degree level of significance $=0.1$

$\mathrm{n}=106 / 1+106(0.01)$

$\mathrm{n}=106 / 1+1.06$

$\mathrm{n}=106 / 2.06$

$\mathrm{n}=51$

$\mathrm{n} 1=\mathrm{Ni}(\mathrm{n}) / \mathrm{N}=93.3(51) / 106=47.6$

$\mathrm{n} 2=\mathrm{Ni}(\mathrm{n}) / \mathrm{N}=4.7(51) / 106=2.4$

$\mathrm{n} 3=\mathrm{Ni}(\mathrm{n}) / \mathrm{N}=1.88(51) / 106=0.96$

Total $=51$

\subsection{Methods of data analysis}

After all the required and relevant data will collect process and strong properly with respect to descriptive analysis which include such as table and percentage in order to achieve the objective the study. 


\section{Data analysis and interpretation}

This chapter dealt with the data analysis and presentation of the data collected for the purpose of analyzing with employment relationship.

Table 4.1 The respondent's sex

\begin{tabular}{|l|c|c|}
\hline \multicolumn{1}{|c|}{ Sex } & Frequency & Percentage \\
\hline Female & 29 & $56.8 \%$ \\
\hline Male & 22 & $43.2 \%$ \\
\hline Total & 51 & $100 \%$ \\
\hline
\end{tabular}

Source: Primary data, 2018

As the above table shows, $56.8 \%$ of respondents are male and $43.2 \%$ of respondents are female.

Table 4.2 The age of respondents

\begin{tabular}{|c|c|c|}
\hline Age group & Frequency & Percentage \\
\hline$<25$ & 10 & $19.6 \%$ \\
\hline $26-30$ & 14 & $27.4 \%$ \\
\hline $31-35$ & 11 & $21.5 \%$ \\
\hline $36-40$ & 9 & $17.6 \%$ \\
\hline$>40$ & 7 & $13.6 \%$ \\
\hline Total & 51 & $100 \%$ \\
\hline
\end{tabular}

Source: Primary data, 2018

As observed from the above table, the majority of respondents (27.4\%) is the age group of 26-30 and a small number of respondents (13.6\%) is the age group of above 40 .

Table 4.3 The respondent's marital status

\begin{tabular}{|l|c|c|c|c|}
\hline \multicolumn{1}{|c|}{ Marital status } & \multicolumn{2}{c|}{ Respondent } & Total & Percentage \\
\hline & male & female & & $12 \%$ \\
\hline Married & 3 & 5 & 20 & $42 \%$ \\
\hline Single & 12 & 8 & 16 & $31 \%$ \\
\hline Unmarried & 6 & 10 & 7 & $15 \%$ \\
\hline Divorced & 3 & 4 & 51 & $100 \%$ \\
\hline Total & 24 & 27 & & \\
\hline
\end{tabular}

Source: Primary data, 2018

The above table shows that the number of both married and single respondents is greater than that of unmarried and divorced.

Table 4.4 The respondent's level of education

\begin{tabular}{|l|c|c|}
\hline \multicolumn{1}{|c|}{ Education level } & Frequency & Percentage \\
\hline Primary school & 10 & $19.6 \%$ \\
\hline Secondary school & 15 & $29.4 \%$ \\
\hline Degree & 6 & $11.7 \%$ \\
\hline Diploma & 20 & $39.2 \%$ \\
\hline Total & 51 & $100 \%$ \\
\hline
\end{tabular}

Source: Primary data, 2018

The above table shows the target respondents' level of education. It reveals that out of total respondents 19\% have completed primary school, $29.4 \%$ - secondary school, the percentage of employees at the level of degree and diploma share is $11.7 \%$ and $39.2 \%$ respectively. Therefore, a large percent of employees are at a diploma level and a small percent of employees are at a degree level.

Table 4.5 The role of private domestic investment

\begin{tabular}{|l|c|c|c|}
\hline \multicolumn{1}{|c|}{ Item } & Responses & Frequency & Percentage \\
\hline Does PDI have & Yes & 27 & $52.9 \%$ \\
\hline Role for the PDI & No & 24 & $47 \%$ \\
\hline Generality employment & Total & 51 & $100 \%$ \\
\hline
\end{tabular}

Source: Primary data, 2018

As seen from the above table, $52.9 \%$ of the responses are yes which means the PDI has a role in employment creation and $47 \%$ of the total respondents replay that PDI has no role in creating employment opportunities. Therefore, in Mettu town the PDI plays a role in generating employment opportunities. 


\subsection{Employment created by PDI sector}

The current status of sectors in the Mettu town is good condition and gives goods and service for the society properly, which are found in and around Mettu town, not only but also by different factors such shortage of land for the investment due to the pressure of investors, lack of capital and poor infrastructure (Mettu town investment office, 2010). In Mettu town even though the number of projects is low in each sector of the economy, currently investors are more motivated to join the investment. As a result, the employment created for the employee also experienced some improves. As the many projects started to operate in the market much employment opportunity has been created (IBID).

Table 4.6 Employment created by PDI sector

\begin{tabular}{|l|c|c|}
\hline Employment created by PDI sector & Frequency & Percentage \\
\hline Male & 32 & $62.70 \%$ \\
\hline Female & 19 & $37.2 \%$ \\
\hline Total & 51 & $100 \%$ \\
\hline
\end{tabular}

Source: Primary data, 2018

Accordingly, the above table shows that the job opportunity created by PDI sector for male is higher $(62.7 \%)$ and the job opportunity for female is low $(37.2 \%)$.

\subsection{Job opportunity created by investment}

A private investor has given the following information.

Table 4.7 Job opportunity created by investment

\begin{tabular}{|l|c|c|c|c|c|}
\hline \multirow{2}{*}{ Types of investment } & \multicolumn{2}{|c|}{ Number of employment } & \multirow{2}{*}{$\begin{array}{c}\text { Total } \\
\text { employment }\end{array}$} & \multicolumn{2}{c|}{ Percentage of employment } \\
\cline { 2 - 3 } \cline { 5 - 6 } & Permanent & Temporary & Permanent & Temporary \\
\hline Service sector & 34 & 30 & 54 & $66.6 \%$ & $73 \%$ \\
\hline Industrial & 10 & 6 & 12 & $19.6 \%$ & $14.64 \%$ \\
\hline Agriculture & 7 & 5 & 9 & $13.7 \%$ & $12.19 \%$ \\
\hline Total & 51 & 41 & 92 & $100 \%$ & $100 \%$ \\
\hline
\end{tabular}

Source: Primary data, 2018

According to the above table, the share of flour factory job create opportunity for 34(66.6\%) and 30(73\%) of permanent and temporary employers respectively among the total number of employees of the service sector. The share of industrial create job opportunity 6(14.64\%) and 10(19.6\%) of permanent and temporary employers respectively.

\subsection{Contribution of PDI in addition to employment creation}

In addition to employment creation products of PDI (sectors such as service, industry and agriculture sector) gives different service for the society different place such as in-home, school office, organization and trade center, etc.

Table 4.8 Contribution of PDI in addition to employment creation

\begin{tabular}{|l|c|c|}
\hline \multicolumn{1}{|c|}{ Respondent } & Frequency & Percentage \\
\hline Yes & 36 & $70.5 \%$ \\
\hline No & 15 & $29.5 \%$ \\
\hline Total & 51 & $100 \%$ \\
\hline
\end{tabular}

Source: Primary data, 2018

The above analysis shows that $70.5 \%$ of respondents that means PDI have a contribution to the society in addition to employment creation and the remaining $29.5 \%$ of respondents replay that the PDI has no contribution to society in addition to employment creation.

\subsection{Precondition to establish private domestic investment}

Before establishing a well-organized PDI they have their own precondition such as human resources, machinery, financial source, experience, working place, etc. 
Table 4.9 Precondition to establish private domestic investment

\begin{tabular}{|l|c|c|}
\hline \multicolumn{1}{|c|}{ Response } & Frequency & Percentage \\
\hline Yes & 39 & $76.47 \%$ \\
\hline No & 12 & $23.5 \%$ \\
\hline Total & 51 & $100 \%$ \\
\hline
\end{tabular}

Source: Primary data, 2018

As indicated by the above table, $76.47 \%$ of respondents response yes that means to establish PDI needs precondition but remaining $23.5 \%$ of respondents replay that precondition is not needed to established PDI. However, in the Mettu town precondition to established PDI is at the rate of $76.47 \%$.

\subsection{Employment creation in investment sector}

PDI in Mettu town has created job opportunities for both permanent and temporary workers. The distribution of PDI in the town gives a high contribution for employment creation in town. From 2007-2010 the total number of employment with its percentage in investment sector in the town is as follows.

Table 4.10 Total number of employment in PDI in 2007-2010

\begin{tabular}{|l|c|c|c|c|}
\hline \multicolumn{5}{|c|}{ Employment condition } \\
\hline Year & Permanent & Temporary & Total No of employment & Percentage of total employment \\
\hline 2007 & 11 & 5 & 16 & $1.26 \%$ \\
\hline 2008 & 220 & 448 & 668 & $50.75 \%$ \\
\hline 2009 & 112 & 228 & 340 & $25.84 \%$ \\
\hline 2010 & 180 & 112 & 292 & $22.19 \%$ \\
\hline Total & 523 & 485 & 1316 & $100 \%$ \\
\hline
\end{tabular}

Source: Mettu town investment office, 2010

According to the information, the contributions of private domestic investment for both permanent and temporary worker in the town is $50.75 \%$ in 2008 and $1.26 \% 2007 \%$ in the high and lower respectively.

\subsection{The share of employment creation in manufacture sector}

PDI in service, industry and agriculture, sectors created by employment opportunity in Mettu town, which produce capital and consumption goods and provide service for the society but among the above sectors the study focused on among three sectors under private investment to evaluate the share employment creation in the Mettu town sector includes the sector such as service, industry and agriculture sectors, etc.

Table 4.11 Share of employment creation in manufacturing sector from 2007-2010

\begin{tabular}{|l|c|c|c|c|}
\hline \multicolumn{1}{|c|}{ Sectors } & No of producer & Capital & Number of employment & Percentage of share \\
\hline Service sectors & 21 & 5444 & 332 & $78.12 \%$ \\
\hline Industry sectors & 14 & 1721 & 60 & $14.12 \%$ \\
\hline Agriculture sectors & 16 & 1935 & 33 & $7.76 \%$ \\
\hline Total & 51 & 9100 & 425 & $100 \%$ \\
\hline
\end{tabular}

Source: Mettu town investment office, 2010

As indicated in the above table, for the last 4 years the total share of employment creation in service sectors was $21(78.12 \%)$ and it creates job opportunity for 332 employers. The total share of employment created industry sector was $14(14.13 \%)$ and it creates job opportunity for 60 of employment, and also the share employment created in agricultural sector was 16(7.79\%) and it creates job opportunity for 33 of employment. In Mettu town, the number of producers in service sectors is more than the two industrial sectors, but the number of employment is found the first level. However, the number of employment is more concentrated in service sector; agricultural sector is found the third level concerning both percentage contributions.

\subsection{Factors that affect investment act in Mettu town}

Environmental factors that affect the investment sector. Start from control and constant monitoring of different types of environment are very essential for investor's survival. Clear environmental factors, which may influence the present and future performance, should be analyzed by investors. 
Business Ethics and Leadership, Volume 3, Issue 4, 2019

ISSN (online) - 2520-6311; ISSN (print) - 2520-6761

As to the response of respondents, there are significant environmental factors that influence the investors' operation in Mettu town. They are:

organization structure;

financial structure;

economic structure such as lack of capital, high taxation;

sociopolitical structure;

delay profession and supply, electricity;

technical and technological structure.

Table 4.12 Factors affecting investment activity in Mettu town

\begin{tabular}{|l|c|c|}
\hline \multicolumn{1}{|c|}{ Factors affecting investment } & Frequency & Percentage \\
\hline Organization structure & 7 & $13.72 \%$ \\
\hline Financial structure & 8 & $15.68 \%$ \\
\hline Economic structure & 11 & $21.58 \%$ \\
\hline Technical and technological structure & 13 & $25.49 \%$ \\
\hline Infrastructure & 7 & $13.72 \%$ \\
\hline Socio political structure & 5 & $9.8 \%$ \\
\hline Total & 51 & $100 \%$ \\
\hline
\end{tabular}

Source: Primary data, 2018

According to the above table, economic structure (25.49\%) is highly affecting private domestic investment sector and $9.8 \%$ of low affecting private domestic investment sector.

\subsection{Major incentive for investors}

The investment incentive for investors includes tax exemption, access for credit, profession of free investment land, financial support, etc. The type of benefits that are granted investors so as to encourage them as per investment proclamation regulation and guidelines issued by the federal and regional government. Based on the federal investment proclamation [No.375/2003] and [No.84/2003], which are providing exemption from income tax exemption from custom duty incentive to investment projects. These investment incentives encourage potential investors in order to invest the resource to bring sustainable development in the town.

Table 4.13 Major incentive for investors

\begin{tabular}{|l|c|c|}
\hline \multicolumn{1}{|c|}{ Incentive } & Frequency & Percentage \\
\hline Tax exemption & 16 & $13.37 \% \%$ \\
\hline Access credit & 20 & $39.21 \%$ \\
\hline Protection & 15 & $29.41 \%$ \\
\hline Total & 51 & $100 \%$ \\
\hline
\end{tabular}

Source: Primary data, 2018

As indicated in the above table, about $31.37 \%$ of respondents agreed upon incentive of tax exemption and the remaining $39.21 \%$ and $29.41 \%$ of respondents agreed upon access of credit and protection respectively. Therefore, the major incentive for investors more concentrated on, tax exemption at the rate of $31.37 \%$ and less on protection at the rate of $29.41 \%$.

\section{Conclusions and recommendations}

\subsection{Conclusions}

The researcher has tried to interpret, present and analysis data from both primary and secondary sources of data. The recommendations of the research on the general operation of the PDI in Mettu town are as follows:

The analysis indicated that the majority of the respondents' sex is male and the majority respondent age is between 26-30. The respondent's marital status, majority respondent for male and female are married and a small number of respondents are divorced but, no one female respondent divorced from sample respondent.

PDI is important to have sustainable economic growth for one town in relative to increase in employment and urbanization. Mettu town is one of the developing towns and needs the alight amount of involving of the private investors to achieve economic growth. It needs also both physical and human capital as well as investors. In addition to this, creating the job opportunity in the town is emerging to minimize the burden of unemployment, which hinders the economic growth of the town. 
The investment used to collected data includes primary and secondary data. Primary data collected through questionnaires and interview while secondary data collected from various document reviews such as books, journal and reports of the CSA. The sample is selected by using purposely and simple random sampling techniques. From a total of 106 investors in the service, industrial and agricultural sectors 51 samples selected to assess the contribution of PDI towards employment creation in Mettu town. After all the required and the relevant data is collected, processed and arranged properly with respect to the descriptive analysis which includes tactical tools such as table and percentage in order to achieve the effectiveness of the study it was found out that the contribution of PDI for permanent and temporary workers in the town is $50.75 \%$ in 2008 and $1.26 \%$ in 2007 in the high and low respectively.

The share of employment creation in the service, industrial and agricultural sector, from the total number of producers in Mettu town was the majority of employment and more concentrated in the service sector which is $78.12 \%$ and less concentrated in agricultural sector which is $7.7 \%$. The level of education of respondents in Mettu town shows that a large percent of employee is at a diploma level which is $39.2 \%$ and a small percent of employee is at a degree level which is $8.333 \%$. Concerning the role of PDI in Mettu town, 52.9\% of respondents reply that the PDI have a role in employment creation and $47 \%$ of the respondents reply that the PDI has no role in creating employment opportunity.

Exceptionally, the more job opportunity is in the sub sectors created by service sector and less job opportunity is icreated by agricultural sector based on their investment size. $70.5 \%$ of respondents in Mettu town reply that the PDI have contribution to the society in addition to the employment creation and the remaining $29.5 \%$ of respondents reply that the PDI has no contribution to the society in addition to employment creation. Generally, the relationship between the private investment and employment creation is positive i.e., the participation of investors increases, there is an increasing in creating job opportunity for employee and as participation of private investors decreases, thare is a decrease in increasing job opportunity for the employees.

\subsection{Recommendations}

$>$ One of the weaknesses of private investors is a lack of adequate managerial skill and experience in identifying profitable and productive opportunity so that the investment office should show direction by identifying profitable project that is consistent with the Mettu town sustainable development.

To increase the participation of investors in Mettu town, the investment office should render different services such as credit, availability, macro finance institution, loans and saving institution as well as infrastructure in Mettu town. Sub-sector has a significant potential in creating job or more employment than other relatively.

The investment office should take remarkable decision in order to facilitate the growth of the town through providing infrastructure such as roads, electricity, water supply etc. which intern initiate the private investors in difference sectors, increasing employment opportunity. On the other hand, decreasing investment leads to low level of employment opportunities. Due to that reason government motivates the investors to improve the positive relationship between investment and employment creation in different ways such as access to credit, tax exemption, free provision urban land etc.

\section{List of Abbreviations:}

CSA - Central Statistical Agency;

EEA - Ethiopian Economic Association;

GDP - growth domestic product;

GNP - growth national product;

IBID - Ibiden (in the same place);

ILO - International Labour Organization;

MOFED - Ministry of Finance and Economic Development;

MED - Minister of Economic Development;

PDI - private domestic investment;

UNCTAD - United Nation Conference on Trade and Development. 


\section{References}

1. Abaka, K. and Mayer, P. (1994). Promotion for Small-scale Enterprises in Ghana. Accra: NBSSI.

2. Ambachew, Mekonnen Sisay (2011). Determinants of private investment in Ethiopia: a time series study. Ethiopian Journal of Economics, Ethiopian Economics Association, 19(1), September. DOI:10.22004/ag.econ.258634.

3. Atkinson, Brian, Milward, Bob and Livesey, Frank (1998). Applied economics; Red Glob Press. Macmillan.

4. Befekadu, Degefe and Berhanu, Nega (1999/2000). Annual report on the Ethiopian economy, Vol. I 1999-2000. Ethiopian Economic Association (EEA publication).

5. Carmen, Reinhart \& Mohsin, Khan (1989). Private investment and economic growth in developing countries, MPRA Paper 13655, University Library of Munich, Germany. Available at: https://mpra.ub.uni-muenchen.de/id/eprint/13655.

6. Deneke, S. (2001). Private Sector Development in Ethiopia. International Conference on African Development Archives: Paper $19 . \quad$ Available http://scholarworks.wmich.edu/africancenter_icad_archive/19.

7. Dollar, D. and Easterly, W. (1999). The Search for the Key: Aid, Investment and Policies in Africa. Journal of African Economies, 8(4), 546-577. Available at SSRN: https://ssrn.com/abstract=915101.

8. Getachew, H. (1997). Determinants of Private Investment in Ethiopia. Journal of African Economies, 7(1), 54-61.

9. History of Encyclopædia Britannica and Britannica Online. Encyclopaedia Britannica, Inc. Archived from the original on 20 October 2006. Retrieved 31 May 2019.

10.Keynes, J.M. (1936). Reprinted in 1994. General theory of employment, interest and money. San Diego: Harcourt Brace Jovanovich. Available at: http://files.ethz.ch/isn/125515/1366 KeynesTheoryofEmployment.pdf.

11.Khan, M. and Reinhart, C.M. (1990). Private Investment and Economic Growth in Developing Countries. World Development, 18(1), 19-27. https://doi.org/10.1016/0305-750X(90)90100-C.

12.Khan, M. and Kumar, M. S. (1997). Public and Private Investment and the Growth Process in Developing Countries. Oxford Bulletin of Economics and Statistics, 59(1), 69-88. https://doi.org/10.1111/1468-0084.00050.

13.Kinfe, Abraham (2001). Ethiopia from empire to federalism. EllPO Press, London. ISBN: 916311982X.

14.Lesotlho, Patrick (2006). An investigation of the determinants of private investment: The Case of Botswana. A mini-thesis submitted in partial fulfillment of the requirements for the degree of Masters (Structured) in Economics, University of the Western Cape. Available at: http://hdl.handle.net/11394/2074.

15.Ministry of Finance and Economic Development (MOFED) (2006). Plan for Accelerated and Sustained Development to End Poverty (PASDEP). Government of Ethiopia (2006).

16.MOFED (2014). Ethiopia's medium term debt management strategy (2013-2014) Addis Ababa, Ethiopia. Available at: https://siteresources.worldbank.org/INTDEBTDEPT/Resources/4689801295462530893/MTDSEthiopia.pdf.

17.Muraga, J. (2006). Determinants of demand for private investment in Kenya. (1970-2003) University of Nairobi Department of Economics, 2006.

18.Ndikumana, L. (2014). Can macroeconomic policy stimulate private investment in South Africa? New insights in to aggregate and manufacturing sector-level evidences. Department of Economics, University of Massachusetts, Amherst.

19. Oshikoya, T. (2001). Macroeconomic Determinants of Domestic Private Investment in Africa: An Empirical Analysis. Economic Development and Cultural Change, 42(3), 573-595. DOI: 10.1086/452103.

20.Ronge, E. and Kimuyu, P. (1997). Private investment in Kenya: trends, composition, and determinants. Institute of Policy Analysis and Research, 1997. P 14.

21.Samuelsson, P. (1989). Economics, 13th edition McGraw-Hill, New Delhi.

22.Shampiro, Edward (2001). Macro Economic Analysis. Harcourt, Brace \& World, New York.

23. Siraj, Mustefa (2014). Private Investment and Economic Growth Evidence from Ethiopia. Mekelle University, School of Graduate Studies. Available at: https://opendocs.ids.ac.uk/opendocs/handle/20.500.12413/4485.

24.Were, M. (2001). The impact of external debt on economic growth and private investments in Kenya: An empirical assessment. Wider Development conference on Debt Relief, Helsinki. Finland: WIDER Development Conference on Debt Relief.

25.Workie, M. (1997). Determinants and constraints of private investment in Ethiopian. Addis Ababa University, Addis Ababa Ethiopia.

26. Yalkonomi lematena tebeber minister (1999). Survey of the Ethiopian Economy: review of post-reform developments (1992/93-1997/98). Ministry of Economic Development and Cooperation (MEDaC), [1999] Addis Ababa. 